\title{
„....wobec rozmiarów Zagłady świat doświadczył ogromnej winy..." Debaty wokół nauczania o Holokauście
}

\begin{abstract}
wobec rozmiarów Zagłady świat doświadczył ogromnej winy i - czując się niezdolny do jej przyjęcia - wolał stłumić wspomnienie zbrodni i pogrążyć się, co najmniej na ćwierćwiecze, w obojętności.
\end{abstract}

M. Janion*

Bywa, że stojąc na drewnianym ganku w dwutysięcznym miasteczku można sobie nagle zdać sprawę, że cztery miliony ludzi nie znalazło swego cmentarza.

J. Janicki, B. Wiernik**

Zagłada Żydów europejskich jest tematem, który zdobył na początku XXI wieku w edukacji krajów Europy Zachodniej, Ameryki Północnej i części krajów Europy Środkowej stałe miejsce na różnych poziomach nauczania w edukacji formalnej i nieformalnej. Nie zawsze tak jednak było. Nasuwa się pytanie, dlaczego zajęło to aż tyle lat? Po zakończeniu II wojny światowej Żydów powracających z obozów koncentracyjnych do domów witano niechętnie nawet w Europie Zachodniej. W przeciwieństwie do członków ruchu oporu, nie otrzymywali rent, np. w Holandii aż do ok. 1970 r. W Polsce miały miejsce pogromy Żydów powracających ze Związku Radzieckiego, którzy zdołali ocaleć.

W Europie Zachodniej dominowały po zakończeniu II wojny światowej wygodne mity jedności narodowej: wyzwolonej Francji De Gaullle'a, jednolitej

* Świadkowie, niewyrażalność i tragedia, Midrasz 2002, nr 6, s. 48.

** Reszta nie jest milczeniem, [w:] Pamiętnik Dawida Rubinowicz. Reszta nie jest milczeniem, Bodzentyn 2010, s. 115. 
w oporze wobec okupanta Holandii. Wydawnictwa skupiały uwagę na wspomnieniach heroicznych, na ruchu oporu. Autorów podręczników historii interesowała historia militarna, walka z Niemcami. Niemcy Zachodnie przyjęły odpowiedzialność za Holokaust, nie bez wewnętrznych debat między zwolennikami i przeciwnikami pogodzenia się z przeszłością, a Niemcy Wschodnie stworzyły autoportret zbiorowy ofiar i bojowników z faszyzmem, całkowicie odcinając się od odpowiedzialności za II wojnę światową. W DDR włączono w szkolnictwie program nauczania z funkcją prewencji i naciskiem na ideologię antyfaszystowską, jako formę politycznej socjalizacji ${ }^{1}$.

Świadomość Zagłady w Europie Zachodniej zaczęła wzrastać w latach 60-tych, wraz ze śledzeniem procesu Eichmanna w 1961 roku i buntem młodzieży w 1968 w Niemczech wobec pokolenia rodziców, których rola w czasie wojny nie była dla młodych jednoznaczna i budziła zrozumiały niepokój. Paradygmaty pamięci narodowych zaczęły stopniowo ulegać dekonstrukcji. Aspekty militarne dotyczące narracji II wojny światowej zaczęły ustępować i z czasem otworzyła się przestrzeń dla pamięci ofiar i wstydliwych tematów postaw państw (w Europie Zachodniej) i społeczeństw (Europy Zachodniej i Środkowo-Wschodniej) wobec prześladowanych Żydów i kolaboracji z III Rzeszą.

W latach 70-tych rozpoczęła działalność niemiecka Akcja Znaku Pokuty zaangażowana $\mathrm{w}$ organizację wizyt $\mathrm{w}$ byłych obozach koncentracyjnych położonych na terenie Polski. Wówczas zaczęła rozwijać się niemiecka pedagogika miejsc pamięci, która nie będzie jednak przedmiotem mojej uwagi w tym artykule, gdyż istnieją — zarówno w Niemczech, jak i w Polsce — bardzo dobre opracowania tego teoretycznie i metodologicznie rozwiniętego nurtu edukacji historycznej łączącego refleksję nad przeszłością z rozwojem postaw społecznych ${ }^{2}$.

Holokaust jako temat szkolny pojawił się w krajach zachodnich w latach 70-tych, przede wszystkim w USA, Kanadzie, Niemczech i w Wielkiej Brytanii — piszą o tym autorki analizy podręczników dotyczącej obecności tematyki Holokaustu i praw człowieka Patricia Bromley i Susan Garnett Russell ${ }^{3}$. Po upadku komunizmu temat Zagłady zaczął pojawiać się także w Europie Środkowo-Wchodniej, a obecnie coraz częściej jest obecny w podręcznikach krajów afrykańskich, azjatyckich i w Australii. Autorki poddały analizie 465 podręczników z lat 1970-2008 z 69 krajów. Holokaust, jak można było przypuszczać, częściej był omawiany w podręcznikach historii niż w podręcznikach wiedzy

${ }^{1}$ G. Wegner, The power of selective tradition: Buchenwald Concentration Camp and Holocaust education for youth in the new Germany, [w:] Censoring History. Citizenship and Memory in Japan, Germany, and the United States, red. L. Hein, M. Selden, Armonk-London 2000, s. 238.

2 T. Kranz, Uwagi na temat rozwoju działalności pedagogicznej muzeów upamiętniania w Polsce i Niemczech, „Zeszyty Majdanka” 2003, t. 22, s. 401-415.

3 P. Bromley, S. Garnett Russell, The Holocaust as History and Human Rights: A Cross-National Analysis of Holocaust Education in Social Science Textbooks, 1970-2008, „Prospects”, marzec 2010, nr 153, s. 153-173. 
o społeczeństwie. W 2000 r. około 70\% książek podejmowało temat Holokaustu w ramach kategorii praw człowieka, co świadczy o wyraźnym przesunięciu dyskursu Holokaustu z perspektywy historycznej w kierunku perspektywy praw człowieka. Optymistyczna ocena tego trendu zakłada, że zrozumienie Holokaustu może pomóc $\mathrm{w}$ demokratyzacji społeczeństw. Temat ten może być postrzegany jako wehikuł promujący tolerancję, zdolny zapewnić pokój i sprawiedliwość. W wersji interpretacji krytycznej, wprowadzenie tematu Holokaustu do edukacji może być traktowane jako przepustka do międzynarodowej społeczności wspólnych norm i wartości europejskich, a nawet, w badaniach Doyle'a Stevicka, jako przepustka do NATO, jak w przypadku Estonii ${ }^{4}$. Ten ostatni przypadek jest spektakularny, ale w wielu innych krajach europejskich członkowstwo w międzynarodowych organizacjach, np. International Holocaust Remembrance Alliance (IHRA) obliguje do politycznych deklaracji i zobowiązań, za którymi niekoniecznie idą $\mathrm{w}$ parze konkretne realizacje na poziomie polityki edukacyjnej danego państwa bądź brakuje mechanizmów wdrożenia zaleceń politycznych do szkolnej praktyki.

Wspomniane autorki ewaluacji podręczników stwierdziły także, że brakuje oceny edukacji o Holokauście w szkolnych klasach. Nie znamy efektów tej edukacji i wpływu nauczania na uczniów. To stwierdzenie wydaje się pojawiać coraz częściej w debatach i także w głosach krytycznych wobec edukacji o Holokauście w jej obecnym formacie, który preferuje podejście kognitywne i zaniedbuje wpływ na postawy uczniów, o czym pisze Piotr Trojański. Będzie to przedmiotem mojej uwagi w dalszej części tekstu.

Trudno oprzeć się wrażeniu, iż edukacja na temat Zagłady nie nadąża za badaniami archiwalnymi. Po początkowej, jak najbardziej słusznej, dokumentacji cierpienia ofiar i badaniach nad architekturą III Rzeszy ${ }^{5}$ w znacznie późniejszych badaniach nad Holokaustem pojawiło się zainteresowanie biurokratami, lekarzami, prawnikami czy księgowymi. Przykładem jest wydana w 2013 r. książka Wendy Lower Hitler's Furies: German Women in the Nazi Killing Fields poruszająca temat nie podejmowany dotychczas, a mianowicie historię rzesz sekretarek i pielęgniarek, bez których mechanizm Zagłady nie mógłby funkcjonować.

Około 20 lat po wprowadzeniu pierwszych programów edukacji o Holokauście, w 1992 roku, Lucy Dawidowicz ${ }^{6}$ narzekała, twierdząc, że istniejące programy i materiały dydaktyczne pozbawione są optyki historycznej, nie znajdują potwierdzenia w źródłach, są powierzchowne, moralistyczne i sentymentalne,

4 Ibidem.

${ }^{5}$ Fundamentalne dzieło Hilberga Zagłada Żydów europejskich oparte na dokumentach niemieckich, tłumaczone w ciągu 6 lat przez Jerzego Giebułtowskiego, ukazało się w Polsce w 2014 r. nakładem Piotra Stefaniuka, politologa i przedsiębiorcy, prezesa Fundacji Wydawnictwa Naukowego TEXTURA.

${ }^{6}$ L.S. Dawidowicz, What Is The Use of Jewish History? Essays, oprac. i wstępem opatrzył N. Kozodoy, New York 1992. 
opierając się na binarnym podziale na złych Niemców i bezbronne żydowskie ofiary. Jak wygląda zatem edukacja o Holokauście 20 lat po sformułowaniu krytycznych uwag przez Lucy Dawidowicz? Mary Jane Rein pisząc o sympozjum „Policy and Practice: Pedagogy about the Holocaust and Genocide”, stwierdziła w rocznym raporcie z 2013/2014 r. Strassler Center for Holocaust and Genocide Studies na Uniwersytecie Clark w USA ${ }^{7}$, że jak dotąd nie doszło do porozumienia w zakresie najlepszych praktyk pedagogicznych. Oznacza to, iż przez około 40 lat, jeśli uznamy lata 70-te za początek edukacji o Holokauście, nie doszło także do zrozumienia, co jest najlepszą praktyką w tej dziedzinie. A zatem, pomimo tak wielu badań, nie mamy wystarczającej ewaluacji istniejących strategii i metod dydaktycznych w zakresie nauczania o Shoah.

Do rozwoju edukacji o Holokauście przyczyniło się wielu badaczy, a w szczególności profesor Uniwersytetu Arkansas w Fayeteville Samuel Totten ${ }^{8}$. Walcząc z kliszami „Pamiętaj” i „Nigdy więcej” zalecał oparcie nauczania o Shoah na wiedzy historycznej i solidne przygotowanie nauczycieli przed podjęciem trudu nauczania o Holokauście w szkołach. Centrum Badań Holokaustu Uniwersytetu Jagiellońskiego stara się realizować zalecenia przygotowania edukatorów do pracy z młodzieżą i od 11 lat szkoli co roku nauczycieli i aktywistów organizacji pozarządowych we współpracy z Instytutem Europeistyki Uniwersytetu Jagiellońskiego, Illinois Holocaust Museum and Education Center w Skokie w USA, Instytutem Pamięci Męczenników i Bohaterów Holokaustu Yad Vashem w Jerozolimie oraz Żydowskim Muzeum Galicja w Krakowie? .

Krytyce nauczania o Holokauście i rekomendacjom towarzyszyła i towarzyszy troska o to, jak uczynić historię ważną dla obecnych i przyszłych pokoleń. Stąd pojawienie się w kontekście edukacji o Holokauście dyskursu dotyczącego

7 http://www.clarku.edu/departments/holocaust/pdfs/yearendreports/2014-strassler-center-annual-report.pdf, s. 13 (dostęp: 15.12.2014).

8 S. Totten, Holocaust Education: Issues and Approaches, Boston 2002.

9 Edukatorzy odwiedzają także Państwowe Muzeum Auschwitz-Birkenau w Oświęcimiu, Międzynarodowy Dom Spotkań Młodzieży w Oświęcimiu i Centrum Żydowskie w Oświęcimiu. Sponsorami Szkoły Letniej Nauczanie o Holokauście byli: Claims Conference, The Conference on Jewish Material Claims Against Germany i indywidualni sponsorzy. Zaproszeni wykładowcy, wybitni nauczyciele akademiccy oraz eksperci z Polski, USA oraz Izraela podzielili się z uczestnikami swoją wiedzą o tym, jak uczyć o Zagładzie i z jakich materiałów korzystać. W gronie zaproszonych ekspertów znaleźli się m.in.: prof. Jan Tomasz Gross, prof. Michael Berenbaum, prof. Zdzisław Mach, prof. Wiesław Kozub-Ciembroniewicz, prof. Jonathan Webber, prof. Andrzej Żbikowski, dr hab. Jolanta Ambrosewicz-Jacobs, dr Natalia Aleksiun, dr Piotr Trojański, dr hab. Dariusz Libionka, Robert Szuchta. W ramach siódmej edycji Szkoły Letniej — Nauczanie o Holokauście odbyły się wykłady, prezentacje, warsztaty, projekcje filmów, dyskusje panelowe i sesje pytań do ekspertów. Ważnym i wzruszającym wydarzeniem było spotkanie z Ocalonym z Holokaustu i wysłuchanie jego historii. W programie seminarium uwzględniono także wizyty w Państwowym Muzeum Auschwitz-Birkenau, Międzynarodowym Domu Spotkań Młodzieży, Żydowskim Centrum Edukacyjnym w Oświęcimiu, wizytę w Żydowskim Muzeum Galicja na Kazimierzu oraz wycieczkę z przewodnikiem po krakowskim Kazimierzu i Podgórzu. 
połączenia uczenia historii Zagłady z edukacją o prawach człowieka i edukacją zapobiegającą ludobójstwom, co będzie przedmiotem mojej uwagi w dalszej części tekstu.

Zanim przejdę do omówienia dyskursu obejmującego edukację zarówno o Zagładzie, jak i na temat praw człowieka oraz przeciwko ludobójstwom którą często łączy się w USA i w niektórych krajach europejskich z nauczaniem o Holokauście - chciałabym najpierw przytoczyć polskich historyków krytycznie odnoszących się do terminu „edukacja o Holokauście”.

Jest to cytat z ważnego tekstu Tomasza Kranza — Pedagogika pamięci jako forma edukacji muzealnej ${ }^{10}$ :

W edukacji historycznej o drugiej wojnie światowej zarysowały się w Polsce w ostatnich dwóch dekadach trzy nurty. Jednym z nich jest program występujący pod nazwą „edukacja o Holokauście" (Holocaust education), który ma wspomagać rozwój szkolnego nauczania historii Szoah, ale także organizację wizyt w miejscach pamięci. Ogólna idea tego projektu, wspieranego przez rządy przeszło 30 państw w ramach struktury działającej jako Grupa Robocza do spraw Międzynarodowej Współpracy w Dziedzinie Edukacji, Upamiętniania i Badań nad Holokaustem (Task Force for International Cooperation on Holocaust Education, Remembrance, and Research - ITF) ${ }^{11}$, zasadza się na powiązaniu nauczania o Holokauście $\mathrm{z}$ wychowaniem moralnym. Jednak mimo zakrojonych na szeroką skalę działań, których celem jest propagowanie wiedzy o zagładzie Żydów i łączenie tego tematu z edukacją o prawach człowieka, trudno uznać Holocaust education za spójną koncepcję dydaktyczną, zwłaszcza w odniesieniu do pracy edukacyjnej muzeów w miejscach pamięci. Zasadniczo nie ma bowiem opracowań naukowych prezentujących założenia teoretyczne i metodologię edukacji o Holokauście jako formę kształcenia pozaszkolnego ${ }^{12}$.

Zasadniczo zgadzam się z uwagami Tomasza Kranza i Piotra Trojańskiego ${ }^{13}$ (omówionymi w dalszej części tekstu) na temat nieistnienia spójnej koncepcji teoretycznej i metodologii $\mathrm{w}$ odniesieniu do mało precyzyjnego terminu „edukacja o Holokauście”. Jak słusznie zauważył Tomasz Kranz, raport Agencji Praw Podstawowych UE odnosi się nie do edukacji o Holokauście per se, ale zgodnie z założeniami konkursu na badania Komisji Europejskiej do edukacji o Holokauście i edukacji o prawach człowieka w muzeach i w miejscach pamięci. Agencja Praw Podstawowych UE (FRA), która zamówiła badania skupiła uwagę

${ }^{10}$ T. Kranz, Pedagogika pamięci jako forma edukacji muzealnej, [w:] Wizyty edukacyjne w Państwowym Muzeum na Majdanku. Poradnik dla nauczycieli, Państwowe Muzeum na Majdanku, Lublin 2012, s. 11-25. Zob. także: idem, Posłowie, [w:] Edukacja Muzealna w Polsce. Aspekty, konteksty, ujęcia, red. W. Wysok, A. Stępnik, Państwowe Muzeum na Majdanku, Lublin 2013, s. 165-172.

11 Aktualna nazwa International Holocaust Remembrance Alliance (IHRA).

12 Wniosek taki nasuwa się po lekturze raportu na temat stanu edukacji o Holokauście w różnych krajach, przygotowanego przez Agencję Praw Podstawowych Unii Europejskiej. Zob. Discover the Past for the Future. A study on the role of historical sites and museums in Holocaust education and human rights education in the EU. Main Results Report, January 2010, http://fra.europa. eu/fraWebsite/attachments/Main-Results-Discover-the-Past-for-the-Future.pdf (dostęp: 9.01.2012).

13 P. Trojański, Edukacja o Holokauście w Polsce. Próba krytycznego bilansu, [w:] Edukacja muzealna ..., s. 129-150. 
wyłącznie na autentycznych miejscach pamięci i muzeach, a to zmienia perspektywę wniosków nasuwających się z raportu. Faktycznie, badania ukazały brak dyskursu, teorii, metodologii, ale $\mathrm{w}$ odniesieniu do obszaru badań dotyczącego potencjalnych związków edukacji o Holokauście i edukacji o prawach człowieka.

Chciałabym jednak poświęcić nieco uwagi pewnym różnicom w postrzeganiu tego zagadnienia. W moim przekonaniu IHRA nie propaguje w jakiś szczególny sposób projektu nauczania o Holokauście, który według Tomasza Kranza „zasadza się na powiązaniu nauczania o Holokauście z wychowaniem moralnym"14. To powiązanie widziałabym raczej jako występujące najczęściej w USA, czasami w formie nieco naiwnej, zwłaszcza w edukacji szkolnej, np. bezpośrednio łączącej przeżycia osoby Ocalałej z doświadczeniem uczniów z najmniej uprzywilejowanych szkół i dzielnic w Nowym Jorku (własna obserwacja uczestnicząca w 1997 r. w szkole średniej w dzielnicy Lower East Side na Manhattanie, w której historycznie osiedlali się i nadal osiedlają się świeżo przybyli imigranci do USA). Przekaz bezpośrednio skierowany był do uczniów i brzmiał: „skoro ja ocalałam, to wy także macie szansę" (w domyśle — wyrwać się z getta etnicznego). W 2013 roku dla amerykańskiej profesorki College'u na Long Island rzeczą oczywistą było, iż edukacja o Holokauście ma wymiar moralny i łączy się z nauczaniem wartości. Gdy próbowałam powiedzieć, iż czasami w Europie edukacja o Holokauście może wywołać, z uwagi na konflikty pamięci, zbiorowe poczucie winy czy rywalizację cierpienia lub/i wtórny antysemityzm, jej reakcja była mieszaniną oburzenia i niedowierzania.

Krytyka edukacji o Holokauście w ujęciu Piotra Trojańskiego, w moim rozumieniu, dotyczy nierealizowania celów wychowawczych oraz tego, że nie ma istotnego komponentu „,prewencji” potencjalnych ludobójstw w przyszłości. Aby ustosunkować się do powyższego krytycznego podejścia należałoby przyjrzeć się współczesnemu dyskursowi wokół pojęcia „edukacja o Holokauście”. Zgadzam się, iż brakuje definicji tego terminu i jest on mglisty, także w optyce szwajcarskiej profesor Monique Eckmann ${ }^{15}$. W roboczej definicji FRA edukacji o Holokauście nie ma według Trojańskiego komponentu prewencyjnego celu dotyczącego teraźniejszości i przyszłości, a nacisk położony jest na upamiętnianie ${ }^{16}$. Postulowana szeroka definicja wymagałaby jednak międzynarodowej debaty, gdyż wiele instytucji edukacyjnych i miejsc pamięci posiada mandat uprawniający do nauczania o historii Holokaustu bądź tylko o historii danego miejsca pamięci, pozostawiając kontekst praw człowieka innym wyspecjalizowanym organizacjom.

Natomiast argument dotyczący nieistnienia połączeń edukacji o Holokauście z przeciwdziałaniem przemocy i ludobójstwom wymaga szerszej analizy współczesnego dyskursu, który dotyczy zarówno ujęcia wyjątkowości Zagłady, jak

14 T. Kranz, Pedagogika pamięci..., s. 11; Zob. także idem, Posłowie, s. 165-172.

15 M. Eckmann, Exploring the Relevance of Holocaust Education for Human Rights Education, „Prospects” 2010, nr 40 (1), s. 7-16.

16 Discover the Past for the Future... 
i traktowania Shoah jako jednego z ludobójstw, uczenia o Holokauście jako fakcie historycznym i podejściu rozpatrującemu Zagładę w kategoriach przeciwdziałania zbrodniom przeciwko ludzkości, obejmującemu kategorie uniwersalnych praw człowieka. Należałoby zacząć od analizy wypowiedzi wybitnego historyka izraelskiego Yehudy Bauera — od początku istnienia ITF (obecnie IHRA) zaangażowanego w jego działania - dotyczącej polaryzacji ujęć Holokaustu jako zjawiska partykularnego lub uniwersalistycznego, co ma implikacje w praktyce edukacyjnej.

Jedna z głównych opozycji w zakresie edukacji o Holokauście, a mianowicie stanowisko wskazujące na wyjątkowość Zagłady Żydów w przeciwieństwie do ujęcia uniwersalistycznego w ujęciu Yehudy Bauera, nie jest realną sprzecznością, chociaż na taką może wyglądać. Otóż według Bauera Holokaust był ludobójstwem i może, a nawet powinien być porównywany z innymi ludobójstwami. Z drugiej strony Holokaust odznaczał się takimi cechami, których nie znajdujemy w innych ludobójstwach. Przede wszystkim wyróżniał się totalnym charakterem (każda jednostka posiadająca trzech lub czterech żydowskich dziadków była skazana na śmierć tylko z powodu urodzenia), globalnością (program zabijania nieograniczony terytorium), antypragmatyczną ideologią (demonizacja Żydów w oparciu o fantazję na temat spisku żydowskiego). Uniwersalny charakter Zagłady dotyczy doświadczenia ludzkiego, które może zostać powtórzone, niekoniecznie wymierzone w Żydów, niekoniecznie w wykonaniu Niemców, ale może uderzyć w kogoś i być zrealizowane przez kogoś i na tym polega unwersalistyczny aspekt Holokaustu, stwierdził Bauer już w 1998 roku podczas spotkania w Sztokholmie zatytułowanego tell ye your children ${ }^{17}$. Skoro doradca akademicki ITF (IHRA) już ponad 15 lat temu wskazywał na brak polaryzacji, skąd taki opór przed przyjęciem takiego punktu widzenia w praktyce? Do tego pytania wrócę po przytoczeniu refleksji nad stanem nauczania o Holokauście.

Jednym z błędnych podejść jest traktowanie obszaru edukacji jako monolitu nieuwzględniającego różnych jej poziomów i różnych aktorów społecznych ustanawiających i realizujących jej założenia. Cele edukacji o Holokauście na poziomie szkoły podstawowej nie są tożsame z celami na poziomie nauczania akademickiego. Organizacje pozarządowe mają inne możliwości i strategie niż szkoły. Marsz Żywych jest odrębną instytucją, której cele nie muszą być tożsame z celami innych instytucji realizujących podstawy nauczania o Holokauście.

Yehuda Bauer, słusznie uważał już w 1998 roku, iż do kształcenia nauczycieli potrzebne są ośrodki akademickie i badania. Od tego czasu powstało ich bardzo dużo, głównie w USA, ale także w Europie, w tym również w Polsce. W pięciu stanach w USA ${ }^{18}$ (Nowy Jork, New Jersey, Floryda, Illinois, California) edukacja na temat Holokaustu jest obowiązkowa, w pozostałych zalecana. W 10 stanach

17 Stockholm Meeting on the Holocaust: Tell Ye Your Children, Summary from the Meeting of 7 May 1998 in Stockholm, Levande Historia.

18 Dane z 2013 r. 
istnieją interdyscyplinarne studia w collegach i na uniwersytetach. Stopnie magisterskie lub certyfikaty oferują m.in. Richard Stockton College w New Jersey w Pomonie, Uniwersytet Texasu w Dallas (Ackerman Center for Holocaust Studies), Uniwersytet Drew w Madison w New Jersey (Holocaust and Genocide Program), Uniwersytet Kean w Union, New Jersey, Keene State College, New Hampshire (Cohen Center for Holocaust and Genocide Studies), Uniwersytet Nevady w Reno, Uniwersytet Vermont w Burlington (Carolyn and Leonard Miller Center for Holocaust Studies), Uniwersytet West Chester w Pennsylwanii. Jedyny program studiów doktoranckich w zakresie studiów nad Holokaustem i ludobójstwami istnieje w Uniwersytecie Clark (Strassler Family Center for Holocaust and Genocide Studies). Typowe połączenie w USA to studia nad Holokaustem i ludobójstwami. W kontekście dyskursu nad wyjątkowością Holokaustu wydawałoby się, że jest to połączenie wykluczające się. Od pewnego czasu jednakże Edukacyjna Grupa Robocza IHRA dyskutuje na możliwością stworzenia modelu nauczania o Holokauście, w którym Zagłada byłaby punktem wyjścia do uczenia się o ludobójstwie i zrozumienia tego zjawiska.

W Europie Zachodniej kursy dotyczące Holokaustu wchodzą głównie w skład oferty dydaktycznej instytutów historii i Holokaust rzadko jest przedmiotem interdyscyplinarnych studiów uniwersyteckich. Oferta interdyscyplinarna jest obecna w programach instytucji pozarządowych, ale raczej w kontekście praw człowieka niż studiów nad ludobójstwami. $\mathrm{Z}$ pewnością mamy ostatnio do czynienia z procesami w edukacji, które obejmują globalizację Holokaustu, ale występują one głównie poza Europą. Na taki stan rzeczy ma wpływ dystans w Europie Zachodniej i w Ameryce Północnej wobec ludobójstw oraz odmienność historii danych krajów, ludobójstw, historii łamania praw człowieka i zbrodni przeciwko ludzkości, które miały miejsce po Holokauście. W Europie Holokaust jest częścią historii europejskiej i częścią historii państw narodowych (wypieranej lub niewypieranej, w zależności od geopolitycznego położenia danego państwa). Na innych kontynentach pozostaje punktem odniesienia: do pokazania symbolu zła, łamania praw człowieka w Europie - kolebce cywilizacji, do modelu transnarodowej sprawiedliwości, do egzemplifikacji, jak można żyć w postkonfliktowych społeczeństwach, do porównania z ludobójstwami, które działy się w innych częściach świata, do nadania rangi traumie wewnątrznarodowej, do upomnienia się o pamięć o ofiarach innych ludobójstw i niesprawiedliwości społecznych.

W kontekście globalnym Holokaust jest studium przypadku ekstremalnego naruszenia praw człowieka i przygotowuje często do spojrzenia na własną narodową bolesną przeszłość. W Argentynie służy jako pryzmat widzenia własnego terroryzmu państwowego i masowej przemocy. W Rwandzie historia Holokaustu zwiększa świadomość dostrzegania faz własnego ludobójstwa. Historia Holokaustu wszędzie pokazuje spektrum postaw ludzkich: sprawców, świadków, ludzi stawiających opór, a także zachowań przekraczających wymienione kategorie bądź przenikających przez nie. W Południowej Afryce pomaga zaangażować się 
przeciwko łamaniu praw człowieka i pomaga także uzyskać dystans wobec własnej przeszłości. W Chinach droga do nauczania o Holokauście wiedzie przez studia judaistyczne na uniwersytetach, na których temat antysemityzmu automatycznie prowadzi do historii Holokaustu. Holokaust staje się także punktem odniesienia do analizy masakry w Nanjing, a modele przełamywania zaprzeczania Holokaustowi są pomocne w przeciwstawianiu się zaprzeczaniu masakrze.

Modele pamięci w Europie, mają związek z rozwojem XIX-wiecznych państw narodowych, a zatem modele pamięci o Holokauście odzwierciedlają historię państw, jawną kolaborację struktur państwowych z III Rzeszą oraz jawną bądź ukrytą kolaborację ich obywateli. Modele pamięci o Holokauście, wraz z wszelkimi różnicami narodowymi, odzwierciedlone są w procesach edukacyjnych, które różni przede wszystkim położenie geopolityczne państw, zachodnie lub środkowo-wschodnie, i stopień uwikłania w Holokaust. W Europie Zachodniej Holokaust stał się negatywnym punktem odniesienia do norm i wartości demokracji, pokazującym grożące jej niebezpieczeństwa i wskazującym na konieczność stałej uwagi wobec zapędów autorytarnych jednostek i grup społecznych. W Europie Środkowo-Wschodniej, po okresie niepamięci, stłumienia i zniekształceń pamięć Holokaustu jest przedmiotem negocjacji, manipulacji politycznych bądź rywalizacji. Interesujące pytania zadała wybitna znawczyni problematyki pamięci w Europie Aleida Assmann podczas seminarium „Remembrance of the Holocaust and Nazi Crimes in Post-1989 Europe", które odbyło się w dniach 15-16 grudnia 2014 roku w austriackiej Akademii Nauk w Wiedniu. Czy w obliczu mnożących się w Europie muzeów i pomników Holokaustu możemy coś powiedzieć na temat ich wpływu na świadomość społeczną? Czy zmieniają one narracje narodowe? Czy włączają one punkt widzenia ofiar czy także zbrodniarzy? Czy Holokaust jest nadal przedstawiany jako „projekt niemiecki”, czy pojawia się tendencja do uznania zbrodni na Żydach jako części „naszej historii”?

W Polsce, której ziemie były epicentrum Holokaustu, nauczanie o Holokauście w niewielkim stopniu odzwierciedla aktualne dyskusje dotyczące uniwersalizacji, globalizacji edukacji o Holokauście czy jej związków z edukacją przeciwko ludobójstwom i/lub edukacją na rzecz praw człowieka. Problemem zasadniczym nauczania o Shoah w Polsce jest to, iż nie ma zarówno miejsca na nauczanie o Zagładzie w programie historii, jak i koordynacji między przedmiotami na poziomie gimnazjum po reformie edukacji w 2008. Brakuje też czasu na omówienie Zagłady, co jest powszechnym problemem z wyjątkiem szkół w Południowej Afryce, gdzie w 9 klasie na omawianie tego tematu poświęca się obowiązkowo 15 godzin lekcyjnych. W wielu szkołach w USA nauczanie o Holokauście stanowi oddzielny moduł w programach szkolnych.

Powoli, po latach nieobecności w narracji, głos oddaje się ofiarom Zagłady, przez wielorakie teksty pamięci: ich świadectwa, wspomnienia, filmy dokumentalne, pomniki, muzea i wystawy. Rośnie jednak rozdźwięk między badaniami historiograficznymi a reprezentacją Zagłady w narracjach szkolnych 
odzwierciedlonych $\mathrm{w}$ podręcznikach ${ }^{19}$. Nadal Shoah jest historią i pamięcią „Ich”, nie naszą. Mimo instytucjonalizacji pamięci i edukacji o Holokauście zapoczątkowanym podpisaniem Deklaracji Sztokholmskiej w 2000 r., dominuje brak odniesień obywatelskich, tak, jakby Holokaust nie objął „,naszych”, polskich obywateli. Ulice polskich miast oznaczone są tablicami upamiętniającymi przelaną polską krew, ale nie ma upamiętnienia w rodzaju „stolpersteine” obecnych w wielu miastach niemieckich, płytek oznaczających domy, z których deportowano żydowskich mieszkańców. Dla wielu polskich nauczycieli temat Zagłady ogranicza się do przekazania faktów historycznych. Postawy Polaków wobec Żydów w czasie Zagłady rzadko przybliżane są uczniom. Jak nauczyciele mogą sobie poradzić z tak poważnym tematem, skoro nawet specjalistom trudno jest wyjaśnić zachowanie ludzkie w czasach terroru, ludobójstwa, w tym sprzeczne zachowania ludzi w czasie Holokaustu.

Wybitny badacz literatury i świadectw Holokaustu Laurence Langer we wstępie do opowiadań Charlotte Delbo ${ }^{20}$, deportowanej do Auschwitz pisarki i członkini ruchu oporu we Francji, podaje przykłady m.in. polskiego granatowego policjanta, który polując na Żydów w dzień, jednocześnie przechowywał wraz $\mathrm{z}$ żoną u siebie w domu żydowską dziewczynkę. Langer pisze, iż nie jest w stanie wythumaczyć takiego zachowania. Podobne fakty stanowią problem dla pamięci o przeszłości. Psychologia społeczna dzięki eksperymentom np. LaPierre'a ${ }^{21}$ dostarcza pewnych wyjaśnień dotyczących zachowań, które są sprzeczne z posiadanymi przekonaniami. Przykładów dostarcza także historia Holokaustu, gdy ludzie przejawiający przed II wojną światową antysemickie poglądy, w obliczu Zagłady Żydów, zmieniali swoje dotychczasowej przekonania i ratowali Żydów. Zofia Kossak-Szczucka narażała swoje własne dzieci, wysyłając je do przeprowadzenia ukrywanych Żydów z jednej kryjówki do drugiej.

Niestety w polskiej szkole rzadko ukazuje się dylematy związane z Zagładą. Powody takiego stanu rzeczy są wielorakie. Należą do nich negatywne wobec nauczania o Holokauście postawy administracji szkolnej i nauczycieli, rodziców i samych uczniów, a także brak wiedzy, również wśród nauczycieli. Lukę tę starało się wypełnić założone w 2003 r. pierwsze w Polsce Centrum Badań nad Zagładą Żydów (CBnZŻ) przy Instytucie Filozofii i Socjologii Polskiej Akademii Nauk skupiające badaczy różnych dyscyplin humanistycznych: historyków, literaturoznawców, socjologów, psychologów. Na uwagę zasługuje wiele publikacji

19 Zob. J. Ambrosewicz-Jacobs, R. Szuchta, The intricacies of education about the Holocaust in Poland. Ten years after the Jedwabne debate, what can Polish school students learn about the Holocaust in history classes?, „Intercultural Education” 25 (4), July 2014, s. 283-299.

20 Ch. Delbo, Auschwitz and after, New Haven-London 1995, s. XII.

21 La Pierre ujawnił niezgodność zachowania z deklarowanymi przekonaniami wśród Amerykanów w latach 30-tych. Podczas podróży z parą zaprzyjaźnionych Chińczyków zatrzymali się w ponad 60 hotelach i około 200 restauracjach i tylko raz nie zostali obsłużeni. Około pół roku po podróży wysłano zapytanie do właścicieli hosteli i restauracji, czy przyjęliby gościa-Chińczyka. Otrzymano 90\% negatywnych odpowiedzi spośród ogólnej liczby 50\% zwrotnych listów. 
CBnZŻ, a dla edukatorów w szczególności „Wybór źródeł do nauczania o Zagładzie Żydów na okupowanych ziemiach polskich” (wraz z CD) oraz „Ćwiczenia ze źródłami" "22. Na stronie www CBnZŻ czytamy:

Wybór źródeł stanowi pomoc dla nauczycieli podejmujących tę problematykę na lekcjach przedmiotów humanistycznych oraz dla uczniów przygotowujących prezentacje maturalne z języka polskiego poświęcone różnym aspektom zagłady Żydów. Wybór źródeł skierowany jest również do szerokiego kręgu odbiorców interesujących się historią najnowszą. Może służyć do pogłębienia wiedzy na temat wydarzeń związanych z Zagładą i pomóc zrozumieć to, co wydarzyło się w sercu Europy w połowie XX wieku ${ }^{23}$.

Aby móc omawiać dylematy moralne związane m.in. z dokonywaniem wyborów w czasach terroru, a także w czasach pokoju, należy najpierw poznać fakty historyczne. Wobec debaty wokół skuteczności edukacji o Zagładzie i proporcji w przekazie między wiedzą a empatią, komponentami poznawczymi a afektywnymi, należy zgodzić się, że historiografia stanowić musi punkt wyjścia. Nauczyciele i uczniowie powinni wiedzieć, kim byli Żydzi, co wnieśli do historii i kultury Europy, jak ginęli i z czyich rąk. Powinni wiedzieć, co wydarzyło się w środku dwudziestowiecznej Europy, jaka była historia narodowego socjalizmu i jakie inne ofiary objęły działania III Rzeszy. Uczeniu o procesach historycznych powinna towarzyszyć pamięć o poszczególnych ofiarach. Historia ofiar nie może być historią dużych liczb, wobec których nie można czuć empatii.

Europa powstała na gruzach II wojny światowej. Pamięć o niej jest pamięcią o destrukcji karmionej nienawiścią etniczną i agresywnym nacjonalizmem. Wobec aktualnej sytuacji w Europie, gdzie przejawy rasizmu, antysemityzmu i nietolerancji są wciąż obecne, a nawet w wielu krajach wzrastają, szczególnie istotnym problemem jest edukacja na temat Auschwitz, Holokaustu oraz problematyki związanej z trudnymi relacjami pomiędzy narodowymi, etnicznymi i religijnymi grupami w Europie. Rasizm, ksenofobia mają miejsce wokół nas i pamięć o Zagładzie winna być przestrogą przed powtórzeniem zbrodni przeciw ludzkości. Nauczanie o Holokauście może stać się metodą walki z ideologią rasistowską, ksenofobią, dyskryminacją, zjawiskom zagrażającym demokracji i może przyczynić się do wzrostu postaw tolerancyjnych wobec imigrantów i innych grup mniejszościowych w społeczeństwie, nie tylko w stosunku do Żydów.

Holokaustowi towarzyszyła bierność świata. Reakcje niezgody, sprzeciwu, pomocy istniały (sprzeciw wobec deportacji „własnych” Żydów — zarówno króla, rządu i kościoła - w Bułgarii, otwieranie wagonów jadących do obozów śmierci przez kolejarzy belgijskich), ale były niewystarczające. Nie było zaangażowania tych, którzy mogli się sprzeciwić, a nie zrobili nic, co obciąża pamięć historyczną

22 B. Engelking, Wybór źródeł do nauczania o Zagładzie Żydów na okupowanych ziemiach polskich, red. A. Skibińska, R. Szuchta, Stowarzyszenie Centrum Badań nad Zagładą Żydów, Warszawa 2010; B. Jędruszczak, W. Młynarczyk, R. Szuchta, Ćwiczenia ze źródłami, Stowarzyszenie Centrum Badań nad Zagładą Żydów, Warszawa 2010.

$23 \mathrm{http}: / /$ www.holocaustresearch.pl/index.php?show=450 (dostęp: 6.01 .2015$)$. 
nie tylko w Europie. Zniknięcie 3 milionów Żydów oraz ich kultury w Polsce nie było niezauważone. Pustka, która po nich została, choć może nieuświadamiana, była $\mathrm{z}$ pewnością odczuwana ${ }^{24}$, o czym świadczy reakcja Polaków na apel Fundacji Shalom i odkrycie przechowywanych w domach polskich fotografii ich żydowskich sąsiadów, a także zainteresowanie studiami nad historią i kulturą Żydów polskich wyrażane przez pokolenia Polaków urodzonych po wojnie.

O Holokauście należy uczyć ze względu na to, że zależy nam na demokracji i poszanowaniu godności ludzkiej. Nie można budować demokracji bez edukacji obywatelskiej. Nie można realizować edukacji obywatelskiej bez edukacji o prawach człowieka, a tej z kolei bez nauczania o Holokauście. Auschwitz to miejscesymbol ludobójstwa ważny dla całej ludzkości, dla Polaków szczególnie, gdyż na miejsce Holokaustu hitlerowcy wybrali ziemie polskie. Ludobójstwo miało miejsce obok naszych przodków, na ich oczach. Dlatego należy uczyć o nim ze świadomością, że gdy my pomijamy milczeniem trudne, bolesne wydarzenia, pytać o nie mogą kolejne pokolenia. Należy uczyć o Zagładzie, ponieważ mało jest znana odmienność losu polskiego i żydowskiego w czasie okupacji. Feliks Tych podaje, iż 95\% Polaków przeżyło okupację, a 98\% Żydów polskich zostało zamordowanych pod niemiecką okupacją ${ }^{25}(90 \% \text { według Aliny Całej })^{26}$. O tej odmienności losu polskiego i żydowskiego też należy uczyć, gdyż młodzież polska nie w pełni zdaje sobie $\mathrm{z}$ tego sprawę, jak wynika $\mathrm{z}$ badań przeprowadzonych prawie 10 lat po upadku systemu, który fałszował prawdę historyczną. Wśród badanych z II klas szkół ponadpodstawowych $\mathrm{w}$ reprezentatywnej ogólnopolskiej próbie 1002 uczniów w 1998 roku 24,5\% młodzieży zgodziło się ze stwierdzeniem, iż w czasie wojny najbardziej ucierpieli Żydzi, 20\% zaprzeczyło, a większość $(55,5 \%)$ wybrała odpowiedź „trudno powiedzieć”. Wielu badanych uczniów wybierało odpowiedzi wymijające w odniesieniu do pytań o postawy wobec Zagłady ${ }^{27}$. Wśród społeczeństwa polskiego w okresie okupacji dominowała bierność i, jak ujęła tę postawę Alina Cała, „sprzyjała jej [bierności] tradycyjna kultura, w której zakorzeniony był w chwilach zagrożenia mechanizm agresji wobec obcych" ${ }^{\text {28 }}$.

Unikanie odpowiedzi na pytanie o cierpienia Żydów w czasie II wojny światowej mogło być spowodowane brakiem informacji, lecz także, w niektórych przypadkach, szczególnie przy trudnych pytaniach, na przykład o pomoc udzielaną Żydom, mogło oznaczać próbę rozwiązania konfliktu, redukcję napięcia związanego z niepewnością, jak postępowali członkowie ich własnych rodzin.

24 A. Cała, Wizerunek Żyda w polskiej kulturze ludowej, [w:] Polska - Polacy-Mniejszości narodowe, Wrocław 1992, s. 215-223.

25 F. Tych, Shoah pamięć zagrożona, „Znak” 2000, nr 6.

26 A. Cała, H. Węgrzynek, G. Zalewska, Historia i kultura Żydów polskich. Słownik, Warszawa 2000, s. 11.

27 J. Ambrosewicz-Jacobs, Me. Us. Them. Ethnic Prejudices and Alternative Methods of Education, Kraków 2003.

28 A. Cała, Wizerunek Żyda..., s. 223. 
Unikanie tematów, pytań, problemów nie jest wszak ich rozwiązywaniem. To tylko odłożenie na bok, tabuizacja zagadnienia wywołującego niepokój. Ale czasami przychodzi czas wewnętrznej potrzeby konfrontacji z przeszłością, i proces ten może objąć zarówno jednostki, jak i społeczności, narody, państwa — jak już wspomniałam we wcześniejszej części tekstu. Rzeczpospolita Polska jest sygnatariuszem przyjętej przez 47 państw w Sztokholmie w styczniu 2000 r. deklaracji zobowiązującej do promowania edukacji o Holokauście, głównie w szkołach oraz jednym z trzydziestu jeden państw członkowskich IHRA. Wśród zadań wynikających z członkostwa RP w IHRA jest dążenie do rozpowszechniania wiedzy i pamięci o Holokauście m.in. przez współpracę w dziedzinie edukacji zarówno na poziomie szkolnictwa ponadpodstawowego, jak i na poziomie szkolnictwa wyższego.

Edukacja o holokauście jest ważna dla studentów polskich. Studenci coraz częściej sięgają po tematy związane z Holokaustem, z postawami Polaków wobec Żydów przed, w czasie, i po wojnie, tematami objętymi tabu w nauce i życiu publicznym przez prawie pół wieku. Tych trudnych i bolesnych tematów nikt studentom nie narzucał. Przyjeżdżając z różnych części Polski na studia do Krakowa, Warszawy, Wrocławia i innych miast, często dopiero tutaj dowiadywali się o mniejszości żydowskiej, którą lata wojny wymazały z krajobrazu społecznego Polski. Ale do niedawna niewielu nauczycieli potrafiło powiedzieć cokolwiek w szkole na temat Zagłady, pogromów, emigracji żydowskiej po 1946 czy 1968 roku.

O Holokauście należy uczyć rzetelnie, w kontekście wiedzy o totalitaryzmie i rasizmie, mechanizmach powstawania negatywnych stereotypów i uprzedzeń, pamiętając, że nie ma jednego wzorca uczenia o Holokauście, pamiętając, iż Holokaust nie był jedynym ludobójstwem w historii. Mamy inne współczesne odniesienia do Holokaustu, np. ludobójstwo Ormian, Romów. Uczenie o Holokauście nie powinno stanowić zagrożenia zbiorowej tożsamości. Uznanie cierpienia narodu żydowskiego nie pomniejsza cierpień innych narodów w czasie okupacji. Ważne jest uznanie, iż cierpienie narodu żydowskiego nie było symetryczne (95\% Polaków przetrwało wojnę). O Holokauście należy uczyć, mając na uwadze tragedię człowieka, nie tragedię abstrakcyjnych milionów. Należy uczyć, uwzględniając to, że negatywne stereotypy i uprzedzenia są przeszkodą w nauczaniu o Holokauście, bez wyłącznej kategoryzacji na sprawców i ofiary, pokazując najbardziej powszechne postawy obojętności i problem moralnych wyborów, dostarczając wiedzy, realizując cele poznawcze nauczania w oparciu o analizę źródeł historycznych, dokumentów i jednocześnie kształtując postawy i uwzględniając ich wielowymiarowy charakter, a zatem realizując cele wychowawcze i kształcąc umiejętności krytycznego myślenia. W nauczaniu o Holokauście istotne jest także odniesienie do aktualnych przejawów antysemityzmu połączone $\mathrm{z}$ analizą źródeł uprzedzeń i nienawiści, które w sprzyjających warunkach mogą doprowadzić do dyskryminujących zachowań. Ludobójstwo szuka ofiar na określonym 
terytorium. Shoa dotknęło Żydów mieszkających na terenach kontrolowanych przez Rzeszę, ale naziści głosili nienawiść do wszystkich Żydów. Po Holokauście antysemityzm powinien zniknąć. Tak się jednak nie stało. I to jest właśnie także jeden z istotnych powodów, dlaczego wciąż należy uczyć o Holokauście.

\section{Bibliografia}

Ambrosewicz-Jacobs J., Me. Us. Them. Ethnic Prejudices and Alternative Methods of Education, Kraków 2003.

Browning Ch., Zwykli ludzie. 101. Policyjny Batalion Rezerwy i „ostateczne rozwiazanie” w Polsce, przeł. P. Budkiewicz Warszawa 2000.

Cała A., Wizerunek Żyda w polskiej kulturze ludowej, [w:] Polska - Polacy - Mniejszości narodowe, Wrocław 1992.

Cała A., Węgrzynek H., Zalewska G., Historia i kultura Żydów polskich. Słownik, Warszawa 2000.

Dawidowicz Lucy S., What Is The Use Of Jewish history? Essays, wstęp i oprac. N. Kozodoy, New York 1992.

Discover the Past for the Future. A study on the role of historical sites and museums in Holocaust education and human rights education in the EU. Main Results Report, January 2010, http:// fra.europa.eu/fraWebsite/attachments/Main-Results-Discover-the-Past-for-the-Future.pdf.

Eckmann M., Exploring the Relevance of Holocaust Education for Human Rights Education, „Prospects" 2010, $\mathrm{nr} 40$ (1).

Engelking B. et al., Wybór źródet do nauczania o Zagładzie Żydów na okupowanych ziemiach polskich, red. A. Skibińska, R. Szuchta, Stowarzyszenie Centrum Badań nad Zagładą Żydów, Warszawa 2010.

Hilberg R., Zagłada Żydów europejskich, t. I-III, Warszawa 2014.

Jędruszczak B., Młynarczyk W., Szuchta R., Ćwiczenia ze źródłami, Stowarzyszenie Centrum Badań nad Zagładą Żydów, Warszawa 2010.

Kranz T., Pedagogika pamięci jako forma edukacji muzealnej, [w:] Wizyty edukacyjne w Państwowym Muzeum na Madanku. Poradnik dla nauczycieli, Państwowe Muzeum na Majdanku, Lublin 2012.

Kranz T., Posłowie, [w:] Edukacja Muzealna w Polsce. Aspekty, konteksty, ujęcia, red. W. Wysok, A. Stępnik, Państwowe Muzeum na Majdanku, Lublin 2013.

Lower W., Hitler's Furies: German Women in the Nazi Killing Fields, Boston-New York 2013.

Totten S., Holocaust Education: Issues and Approaches, Boston 2002.

Trojański P., Edukacja o Holokauście w Polsce. Próba krytycznego bilansu, [w:] Edukacja Muzealna w Polsce. Aspekty, konteksty, ujęcia, red. W. Wysok, A. Stępnik, Państwowe Muzeum na Majdanku, Lublin 2013.

Wegner G., The Power of Selective Tradition: Buchenwald Concentration Camp and Holocaust Education for Youth in the New Germany, [w:] Censoring History. Citizenship and Memory in Japan, Germany, and the United States, red. L. Hein, M. Selden, Armonk-London 2000. 


\section{„...THE WORLD FELT A HUGE GUILT OVER THE SCALE \\ OF THE HOLOCAUST...”. DEBATES SURROUNDING THE TEACHING \\ ABOUT THE HOLOCAUST}

\section{Summary}

In Europe a strong association with a sense of victimhood based on the memory of terror and murder in many cases creates conflicting approaches and generates obstacles to providing education about Jewish victims. Suppressed shame and tension together with conflicts related to insufficiently acknowledged victimhood of one's own group intersect with political agreements on teaching about the Shoah such as the signing of the Stockholm Declaration and membership in the IHRA and other IGOs. The text presents selected challenges and the dynamics of education about the Holocaust and poses questions such as whether it is possible to identify clear concepts, strategies and good educational practices, whether there are links between education about the Holocaust, education against genocides and human rights education, and how education about the Holocaust relates to attitudes toward Jews? In many European countries disparities have grown between Holocaust research and education about the Holocaust. Empirical studies in the field of education reveal that there is a gap between research and education in some aspects of the way the Holocaust is presented, particularly with regard to the attitudes of local populations towards Jews during the Shoah. Nevertheless, the number of educational initiatives designed to teach and learn about the Shoah is steadily increasing.

Keywords: Holocaust, Shoah, teaching, history, historical policy, post-communism.

Jolanta Ambrosewicz-Jacobs

jolanta.ambrosewicz-jacobs@uj.edu.pl 